\title{
Penerapan Inovasi Teknologi Pertanian dan Hubungannya dengan Ketahanan Pangan Rumah Tangga Petani
}

\section{The Adoption of Agricultural Technology Innovation and its Correlation with Food Security of Farmer Households}

\author{
Anna Fatchiya ${ }^{1}$, Siti Amanah ${ }^{1}$, Yatri Indah Kusumastuti ${ }^{1}$ \\ ${ }^{1}$ Departemen Sains Komunikasi dan Pengembangan Masyarakat, Fakultas Ekologi Manusia, \\ Institut Pertanian Bogor, Bogor
}

\begin{abstract}
The adoption of agricultural technology innovation plays a role to increasing production, so the opportunity to improve the farmer's well-being, one of which is indicated by increasing food security of farmer households. This study aimed to identify the innovation of agricultural technology that has been adopted by farmers in the study area, and analyze its correlation with food security of farmer households. Research methods such as surveys in two villages in Bogor District that have different types of agriculture that is dry and wet land (paddy fields), with a sample size of 80 people. Data were analyzed with statistical test of Rank Spearman. The results showed that most farmers in the paddy field has been adopting technological innovations in system "Legowo" ("roomy lined row") intensively, and farmers in dry land has been adopting innovation intercropping system and agricultural processing (on-farm) intensively too. Adoption of this technology is positively correlated with farmer households' food security, the farmers who adopt more intensive technological innovations have higher levels of food security.
\end{abstract}

Keywords: Agriculture, adoption, food security, technology innovation

\begin{abstract}
Abstrak
Penerapan teknologi inovasi pertanian berperan dalam meningkatkan produktivitas usaha tani, sehingga berpeluang untuk meningkatkan kesejahteraan hidup, yang salah satunya diindikasikan dari meningkatnya ketahanan pangan rumah tangga petani.Penelitian ini bertujuan untuk mengindentifikasi inovasi teknologi pertanian yang telah diterapkan di lokasi studi, dan menganalisis hubungannya dengan kondisi ketahanan pangan pada rumah tangga petani. Metode penelitian berupa survei di dua desa di Kabupaten Bogor yang masing-masing memiliki tipe pertanian yang berbeda yaitu lahan kering dan basah (sawah), dengan jumlah sampel sebanyak 80 orang. Data dianalisis dengan uji statistik Rank Spearman. Hasil penelitian menunjukkan bahwa sebagian besar petani di lahan sawah telah menerapkan inovasi teknologi berupa sistem jajar legowo secara intensif, dan petani di desa berlahan kering cukup intensif dalam menerapkan inovasisistem tumpang sari dan pengolahan hasil pertanian (on farm).Penerapan teknologi ini berkorelasi positif dengan kondisi ketahanan pangan rumah tangga petani, yaitu petani yang menerapkan inovasi teknologi lebih intensif memiliki tingkat ketahanan pangan yang lebih baik.
\end{abstract}

Kata kunci: Pertanian, adopsi, ketahanan pangan, inovasi teknologi

\section{Pendahuluan}

Inovasi teknologi pertanian berperan penting dalam meningkatkan produktivitas pertanian, mengingat bahwa peningkatan produksi melalui perluasan lahan (ekstensifikasi) sulit diterapkan di Indonesia, di tengah-tengah konversi lahan pertanian produktif ke non pertanian semakin meluas. Menurut data Badan Pusat Statistik (BPS) dalam kurun waktu 1983-1993 telah terjadi alih fungsi lahan seluas 935.000 hektar yang terdiri atas 425.000 hektar berupa lahan sawah dan 510.000 lainnya bukan sawah atau rata-rata pertahun sekitar 40.000 hektar. Untuk tahun 1993-2003 diperkirakan konversi lahan mencapai dua kali lipat dari tahun 1983-1993, yaitu sekitar 80.000 hingga 100.000 hektar per tahun.Wilayah konversi lahan terbesar terjadi di Pulau Jawa sebesar 54\% dan Sumatera 38\%. Perubahan konversi lahan terbesar adalah menjadi lahan perkampungan/lahan pemukiman (69 persen) dan kawasan industri (20 persen).

Petani sebagai ujung tombak pembangunan pertanian berperan sangat penting dalam meningkatkan produktivitas hasil pertanian, mengingat bahwa petani sebagai pelaku utama pertanian. Inovasi teknologi pertanian tidak akan ada manfaatnya, jika petani tidak menggunakannya. Oleh karena itu, pengadopsian inovasi teknologi ini oleh petani penting guna meningkatkan produktivitas usahatani. Secara makro

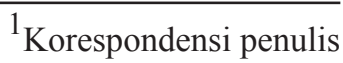

${ }^{1}$ Korespondensi penulis
E-mail: annafatchiya@yahoo.com 
pemerintah berkepentingan untuk meningkatkan produksi pertanian, karena selama ini kebutuhan pangan seluruh masyarakat Indonesia masih menggantungkan dari impor.Bahkan nilai impor pangan dari tahun ke tahun semakin meningkat. Data BPS menunjukkan bahwa selama semester I 2011 (Januari-Juni), Indonesia telah mengimpor bahan pangan mentah maupun olahan, senilai 5,36 milliar dollar AS dengan volume impor mencapai 11,33 juta ton, dan pada tahun 2013 meningkat mencapai 15,4 juta ton atau setara dengan US\$ 7,73 miliar. Indonesia mengimpor sedikitnya 28 komoditi pangan mulai dari beras, jagung, kedelai, gandum,terigu, gula pasir, gula tebu, daging sapi, daging ayam, sampai singkong.

Pada tataran mikro, yaitu rumah tangga petani, penggunaan teknologi pertanian yang inovatif diperlukan untuk meningkatkan hasil panen petani. Dengan demikian pendapatan petani meningkat, dan kondisi ketahanan pangan rumah tangganya semakin kuat.Hasil penelitian Amirian et al. (2008) dan Suhardianto (2007) menunjukkan pendapatan dan produktivitas pertanian berhubungan positif signifikan dengan ketahanan pangan rumah tangga petani. Namun demikian tidak semua petani mau dan mampu dalam menggunakan inovasi teknologi, meskipun inovasi ini telah diprogramkan dalam kegiatan-kegiatan di lingkup Kementerian Pertanian. Beberapa hasil penelitian menunjukkan bahwa inovasi teknologi yang telah diintroduksikan kepada masyarakat petani beberapa diantaranya tidak diadopsi lebih lanjut oleh petani, misalnya pada pengendalian hama terpadu (Nilasari et al., 2016) yang diantaranya disebabkan oleh tingkat kerumitan dan kurang menguntungkan hasil dari inovasi tersebut. Sebagaimana yang dinyatakan oleh Rogers (2003) bahwa sifat-sifat inovasi akan menentukan petani untuk mengadopsi atau tidak suatu inovasi, yaitu dari sifat keuntungan relatif, kesesuaian, kerumitan, kemudahan dicoba, dan dapat dibedakan dengan yang lama.

Keuntungan relatif (relative advantages) adalah tingkatan ketika suatu ide baru dianggap suatu yang lebih baik daripada ide-ide yang ada sebelumnya. Tingkat keuntungan relatif seringkali dinyatakan dengan atau dalam bentuk keuntungan ekonomis. Kesesuaian inovasi (compatibility) adalahkesesuaian dengan tata nilai maupun pengalaman yang ada, pengalaman masa lalu dan kebutuhan penerima. Ide yang tidak kompatibel dengan ciri-ciri sistem sosial yang menonjol akan tidak diadopsi secepat ide yang kompatibel. Kompatibilitas memberi jaminan lebih besar dan resiko lebih kecil bagi penerima dan membuat ide baru itu lebih berarti bagi penerima. Kerumitan (complexity) adalah tingkat ketika suatu inovasidianggap relatif sulit untuk dimengerti dan digunakan. Suatu ide baru mungkin dapat digolongkan ke dalam kontinum "rumit-sederhana". Kerumitan teknologi menurut pengamatan anggota sistem sosial, berhubungan negatif dengan kecepatan adopsinya. Ini berarti makin rumit suatu inovasi bagi seseorang, maka akan makin lambat pengadopsiannya. Kemudahan untuk diujicoba (trialability) adalah suatu tingkat ketika teknologi dapat dicoba dengan skala kecil. Ide baru yang dapat dicoba biasanya diadopsi lebih cepat dari pada inovasi yang tidak dapat dicoba terlebih dahulu. Kemudahan untuk diamati (observability) adalah tingkat ketika hasil-hasil suatu inovasi dapat dilihat oleh orang lain. Hasil inovasi-inovasi tertentu mudah dilihat dan dikomunikasikan kepada orang lain.

Guna mengetahui jenis-jenis inovasi teknologi apa saja yang telah diterapkan oleh petani di lokasi studi dan sejauhmana intensitasnya dalam menggunakan inovasi tersebut, serta hubungannya dengan kondisi ketahanan pangan rumah tangga, maka dilakukan penelitian ini. Dengan demikian tujuan penelitian ini adalah untuk: (1) mengidentifikasi jenis-jenis inovasi teknologi pertanian yang telah dikenal oleh masyarakat petani dan mengukur intensitasnya, dan (2) menganalisis hubungan antara adopsi inovasi teknologi pertanian dengan tingkat ketahanan rumah tangga petani.

\section{Metode Penelitian}

Penelitian dilakukan di dua kelompok tani di Kabupaten Bogor yang mewakili petani dengan fokus usaha yang berbeda, yaitu pertanian lahan basah (sawah) yang berada di Desa Cibeber I, Kecamatan Leuwiliang dan pertanian lahan kering dan pengolahan hasil pertanian di Desa Benteng, Kecamatan Ciampea. Penelitian ini didesain dengan menggunakan survei yaitu pengumpulan data dengan menggunakan kuisoner, dan diperdalam dengan pendekatan Focus Group Discussion (FGD), wawancara mendalam, serta observasi terhadap kondisi sosial, ekonomi, budaya, lingkungan lokasi studi, serta teknologi usahatani yang digunakan oleh masyarakat petani setempat.

Jumlah anggota kelompok tani di dua desa penelitian adalah 40 orang dengan menggunakan sampel acak sederhana (sample random sampling).Data yang telah terkumpul dianalisis secara statistik deskriptif 
berupa jumlah dan persentase dan statistik inferensial dengan menggunakan uji Rank Spearman.

\section{Hasil dan Pembahasan}

\section{Pola Usaha Tani}

Berdasarkan status penguasaan lahan, sebagian besar responden di kedua desa penelitian berupa bagi hasil (Tabel 1). Umumnya responden tidak memiliki lahan sendiri, mereka hanya mengolah lahan dari pemilik dan mendapatkan pendapatan dari hasil panen yang dibagi sesuai kesepakatan sebelumnya. Banyak kasus bahwa dulunya lahan tersebut milik sendiri atau milik keluarga (orang tua) yang dijual kepada orang lain, tetapi pembeli lahan tidak mengusahakannya. Selain mengolah lahan yang dulu milik sendiri, ada juga yang memang sejak awal tidak pernah memiliki lahan sendiri. Kondisi ini dapat mendorong pada pemiskinan petani, sebagaimana yang disinyalir oleh Geertz dengan istilah involusi pertanian.

Terdapat perbedaan jenis komoditas pertanian yang diusahakan oleh responden di kedua lokasi penelitian.Untuk Desa Benteng didominasi tanaman palawija dan hortikultura, sedangkan di Desa Cibeber I didominasi tanaman pangan berupa padi sawah. Perbedaan ini terkait dengan perbedaan agroekosistem di kedua lokasi tersebut. Lahan di Desa Benteng sebagian besar berupa perladangan dengan tingkat kesediaan air yang rendah, sebaliknya di Desa Cibeber
I berupa hamparan persawahan yang cenderung basah dengan ketersediaan air yang lebih banyak.Di samping itu, tingkat konservasi lahan yang cukup tinggi di Desa Benteng mendorong perubahan areal persawahan menjadi pemukiman, sehingga banyak saluran irigasi tertutup dan segregasi sawah menjadi lahan-lahan yang berukuran sempit. Pertanian di Desa Benteng juga lebih bervariatif dibandingkan dengan Desa Cibeber I, selain tanaman palawija dan hortikultura, juga dikembangkan tanaman obat, budidaya ikan, dan pengolahan hasil pertanian berupa keripik singkong.

\section{Penerapan Inovasi Teknologi Pertanian}

Penerapan inovasi di wilayah pedesaan Indonesia, termasuk di Kabupaten Bogor berhubungan erat dengan penyelenggaraan penyuluhan. Pada tingkat kabupaten dilakukan oleh Badan Pelaksana Penyuluhan (UU No 16 Tahun 2006), dan di Kabupaten Bogor badan ini bernama Badan Ketahanan Pangan dan Pelaksana Penyuluhan Pertanian Perikanan Kehutanan (BP5K). Pada tingkat kecamatan penyuluhan diselenggarakan oleh Balai Penyuluhan Pertanian Perikanan Kehutanan (BP3K).

Penyuluh lapang berperan penting dalam memperkenalkan inovasi teknologi pertanian kepada petani. Peran penyuluh pada dasarnya tidak hanya sekedar memperkenalkan teknologi kepada petani, melainkan juga meningkatkan kapasitas petani agar mampu secara mandiri dalam menjalankan usahanya.

Tabel 1. Jumlah dan Persentase Responden berdasarkan Status Penguasaan Lahan di Desa Benteng dan Desa Cibeber I, 2015

\begin{tabular}{lcccc}
\hline \multirow{2}{*}{$\begin{array}{l}\text { Status penguasaan } \\
\text { lahan }\end{array}$} & \multicolumn{2}{c}{ Desa Benteng } & \multicolumn{2}{c}{ Desa Cibeber I } \\
\cline { 2 - 5 } Lahan milik sendiri & Jumlah (orang) & Persentase (\%) & Jumlah (orang) & Persentase (\%) \\
Lahan sewa & 16 & 40,0 & 15 & 37,5 \\
Lahan bagi hasil & 2 & 5,0 & 0 & 0,0 \\
Kolam & 20 & 50,0 & 23 & 57,5 \\
Lahan sendiri + bagi & 3 & 7,5 & 1 & 0,0 \\
hasil & 0 & 0,0 & 1 & 2,5 \\
Lahan sewa + bagi & 0 & 0,0 & 40 & 2,5 \\
hasil & 40 & 100,0 & & 100,0 \\
\hline Total & & & & \\
\hline
\end{tabular}


Kapasitas sebagai agregat dari kemampuan dan kompetensi, yang di dalamnya tercakup daya adaptif, kemampuan menjalankan fungsi, memecahkan masalah, dan merencanakan dan mengevaluasi suatu usaha. Tingkatan kapasitas seseorang akan menentukan kemandiriannya, yaitu dengan semakin tinggi tingkat kapasitasnya, maka semakin tinggi pula tingkat kemandiriannya.

Jenis inovasi teknologi pertanian yang diterapkan di kedua desa penelitian berbeda, karena agroekosistem di kedua desa tersebut juga berbeda. Lahan yang diusahakan responden di Desa Benteng berupa lahan kering, yaitu tegalan dengan jenis tanaman palawija, hortikultura, dan obat-obatan, sedangkan di Desa Cibeber I berupa persawahan dengan jenis tanaman utama padi.

Tidak banyak inovasi teknologi yang diterapkan di kedua desa penelitian (Tabel 2). Di Desa Benteng pada budidaya tanaman hanya berupa sistem tumpang sari dan penggunaan polybag sebagai media tanam, perikanan berupa pembenihan, dan pengolahan hasil pertanian berupa penggunaan mesin pengolahan.Pada sistem tumpangsari, petani menanam dua atau lebih jenis tanaman palawija atau hortikultura pada satu bidang lahan, misalnya kacang panjang dengan timun, singkong dengan cabai dan sebagainya.Kelebihan tumpang sari atau double-cropping antara lain menekan jumlah hama, karena hama tanaman tidak menyukai tanaman tumpangsari(Agrotani 2016). Secara ekonomi, tumpangsari meningkatkan pendapatan petani dan mengurangi resiko kerugian dari kegagalan panen salah satu tanaman.

Teknologi inovasi pembenihan ikan yang dikenal oleh petani di Desa Benteng adalah penggunaan induk unggul dan pemijahan induk, meskipun belum semua pembudidaya ikan menerapkan inovasi ini. Pada umumnya pembudidaya ikan menggunakan indukan bukan unggul tetapi hasil seleksi dari hasil panennya sendiri. Secara umum pembenihan ikan yang dilakukan pembudidaya ikan di Bogor dilakukan secara tradisonal (Fatchiya, 2010)

Pada pengolahan hasil pertanian, responden telah menggunakan mesin pengolahan yang sebelumnya dilakukan secara manual dengan alat tradisional, misalnya mesin pemotong singkong dan ubi jalar menggantikan pisau manual, sehingga pekerjaan menjadi lebih mudah dan cepat dengan hasil yang lebih berkualitas.

Inovasi teknologi yang diterapkan pada usahatani padi di Desa Cibeber I hanya berupa jajar legowo, sedangkan System Rice Intensification (SRI) yang sudah menjadi tren pertanian dunia seperti halnya juga pertanian organik belum dikenal oleh masyarakat tani. Sistem jajar legowo secara intensif diperkenalkan oleh penyuluh pertanian kepada masyarakat tani di Desa Cibeber I. Petani diperkenalkan pola jarak

Tabel 2. Jumlah dan Persentase Responden berdasarkan Jenis Inovasi Teknologi Pertanian yang Diterapkan di Desa Benteng dan Desa Cibeber I, 2015

\begin{tabular}{lcccc}
\hline \multirow{2}{*}{ Inovasi Teknologi } & \multicolumn{2}{c}{ Desa Benteng } & \multicolumn{2}{c}{ Desa Cibeber I } \\
\cline { 2 - 5 } & $\begin{array}{l}\text { Jumlah } \\
\text { (orang) }\end{array}$ & Persentase (\%) & $\begin{array}{c}\text { Jumlah } \\
\text { (orang) }\end{array}$ & $\begin{array}{c}\text { Persentase } \\
\text { (\%) }\end{array}$ \\
\hline Lahan kering & & & & \\
Sistem tumpang sari & 14 & 35,0 & 1 & 2,5 \\
Polybag & 5 & 12,5 & 0 & 0,0 \\
Konvensional & 15 & 37,5 & 0 & 0,0 \\
Lahan sawah & 0 & 0,0 & 0 & 0,0 \\
SRI & 0 & 0,0 & 39 & 97,5 \\
Jajar legowo & 0 & 0,0 & 0 & 0,0 \\
Tanaman organik & & & & 0,0 \\
Perikanan & 3 & 7,5 & 0 & 0,0 \\
Pembibitan ikan & & & & \\
Pengolahan & 7 & 17,5 & 0 & \\
Mekanisasi (mesin) & & & & \\
\hline
\end{tabular}


tanam tertentu dengan lajur yang lurus, dengan tujuan utama meningkatkan efisiensi penggunaan input dan memudahkan mekanisme kerja, serta meningkatkan produktivitas padi. Melalui jajar legowo, produktivitas padi bisa meningkat antara 14 sampai 30 persen per hektarnya (BBPP Ketindan 2016)

Tingkat penerapan inovasi teknologi pertanian tersebut oleh responden cukup baik, meskipun tidak banyak jenis inovasi teknologi yang ada. Hal ini terlihat dari mayoritas responden menyatakan selalu menerapkan inovasi tersebut, yaitu sebesar $77,5 \%$ di Desa Benteng dan 92,5\% di Desa Cibeber I (Tabel 3). Dilihat dari tingkatan adopsinya, Desa Cibeber I lebih baik dibandingkan dengan Desa Benteng.Persentase responden di Desa Cibeber I yang selalu menerapkan lebih tinggi dan tidak ada yang berhenti menerapkan inovasi jajar legowo tersebut.Sebaliknya di Desa Benteng dijumpai adopter yang berhenti mengadopsinya.Salah satu alasan yang dikemukakan oleh responden yang berhenti mengadopsi teknologi adalah harga jual produk tidak berbeda antara yang menggunakan teknik baru atau lama.

Lippitt (1969) menyatakan adanya sembilan situasi yang menyebabkan masyarakat resisten terhadap perubahan, yaitu (1) ketika tujuan perubahan tidak jelas, (2) ketika masyarakat tidak dilibatkan dalam perencanaan, (3) ketika seruan tidak didasarkan pada alasan personal, (4) ketika norma dan kebiasaan masyarakat tidak diindahkan, (5) ketika komunikasi untuk berubah sangat jelek; (6) ketika ada rasa takut gagal, (7) ketika biaya terlalu mahal atau tidak sebanding dengan manfaatnya, dan (8) ketika situasi yang ada sudah cukup memuaskan, maka seorang penyuluh atau agen pembaharuan perlu melakukan pendekatan yang lebih intensif pada masyarakat ini, agar bisa tergali dengan jelas "kondisi psikologis" yang dirasakan oleh mereka yang nantinya bisa dijadikan untuk melakukan perubahan perilaku dari seorang petani tradisional menjadi petani "pengusaha".

Menurut Rogers dan Shoemaker (1993) seseorang menerima atau menolak inovasi, melalui tahapan proses pengambilan keputusan yaitu (1) tahap pengetahuan atau pengenalan, dimana sasaran mengetahui adanya inovasi dan telah memperoleh pengertian atau persepsi bagaimana inovasi itu berfungsi; (2) tahap persuasi, dimana sasaran membentuk sikap setuju atau tidak setuju terhadap inovasi; (3) tahap keputusan, dimana sasaran terlibat dalam kegiatan untuk menerapkan atau tidak menerapkan; (4) tahap implementasi, dimana sasaran menerapkan di lapangan apayang telahmenjadikeputusanya;(5)tahapkonfirmasi, dimana sasaran dalam hal ini mencari kekuatan bagi keputusannya yang telah diambil dalam menerapkan atau menolak inovasi. Pernyataan tersebut memberi arti bahwa dalam proses adopsi petani memerlukan dasardasar pertimbangan yang dianggap benar, baik dan layak dilakukan untuk diri sendiri maupun di lingkungan sekitarnya. Petani masih memerlukan pertimbangan dan pengabsahan dari pihak lain baik secara individu maupun kelembagaan mengenai kelayakan inovasi.

Proses adopsi dapat terjadi tanpa berurutan mengikuti tahapan, artinya proses adopsi inovasi terjadi begitu cepatnya seakan-akan melompat pada kondisi mengerti atau sadar langsung pada menerapkan tanpa melalui pertimbangan yang matang. Sebaliknya, ada pula tahapan yang berhenti pada keadaan berminat saja tanpa kelanjutan pada tahap berikutnya yaitu mencoba dan menilai hingga menerapkan.

\section{Ketahanan Pangan Rumah Tangga Petani}

Ketahanan pangan rumah tangga petani dicirikan

Tabel 3. Jumlah dan Persentase Responden berdasarkan Intensitas Penerapan Teknik Pertanian di Desa Benteng dan Desa Cibeber I, 2015

\begin{tabular}{lcccc}
\hline \multirow{2}{*}{ Intensitas penerapan teknologi } & \multicolumn{2}{c}{ Desa Benteng } & \multicolumn{2}{c}{ Desa Cibeber I } \\
\cline { 2 - 5 } & Jumlah (orang) & Persentase (\%) & Jumlah (orang) & Persentase (\%) \\
\hline Selalu & 31 & 77,5 & 37 & 92,5 \\
Kadang-kadang & 1 & 2,5 & 3 & 7,5 \\
Belum/berhenti & 8 & 20,0 & 0 & 0,0 \\
\hline \multirow{2}{*}{ Total } & 40 & 100,0 & 40 & 100,0 \\
\hline
\end{tabular}


Tabel 4. Jumlah dan Persentase Responden berdasarkan Persepsi Reseponden atas Ketersediaan Pangan dalam Rumah Tangga di Desa Benteng dan Desa Cibeber I, 2015

\begin{tabular}{lcccc}
\hline \multirow{2}{*}{ Ketersediaan pangan } & \multicolumn{2}{c}{ Desa Benteng } & \multicolumn{2}{c}{ Desa Cibeber I } \\
\cline { 2 - 5 } & $\begin{array}{l}\text { Jumlah } \\
\text { (orang) }\end{array}$ & Persentase (\%) & $\begin{array}{c}\text { Jumlah } \\
\text { (orang) }\end{array}$ & Persentase (\%) \\
\hline Sangat cukup & 1 & 2,5 & 3 & 7,5 \\
Cukup & 32 & 80,0 & 29 & 72,5 \\
Kurang & 7 & 17,5 & 8 & 20,0 \\
Sangat Kurang & 0 & 0,0 & 0 & 0,0 \\
\hline Total & 40 & 100,0 & 40 & 100,0 \\
\hline
\end{tabular}

dari ketersediaan pangan yang cukup dalam rumah tengga tersebut. Sesuai dengan yang dinyatakan dalam Undang-Undang Nomor 18 Tahun 2012 tentang Pangan bahwa ketahanan pangan sebagai kondisi terpenuhinya pangan bagi negara sampai dengan perseorangan, yang tercermin dari tersedianya pangan yang cukup, baik jumlah maupun mutunya, aman, beragam, bergizi, merata, dan terjangkau serta tidak bertentangan dengan agama, keyakinan, dan budaya masyarakat, untuk dapat hidup sehat, aktif, dan produktif secara berkelanjutan.

Kondisi ketahanan pangan rumah tangga petani dalam penelitian ini dilihat dari kecukupan pangan, keterjangkauan atau kemudahan mendapatkan pangan di sekitar tempat tinggal, dan keterjangkauan atau daya beli pangan berdasarkan persepsi responden.Secara terinci pada deskripsi berikut dijelaskan tentang kondisi ketahanan pangan rumah tangga tersebut.

Berdasarkan kecukupan bahan pangan yang ada dalam rumah tangga, responden di kedua lokasi penelitian menunjukkan adanya ketersediaan yang cukup (Tabel 4). Mayoritas responden, $80 \%$ di Desa Benteng dan $72,5 \%$ di desa Cibeber I menyatakan bahwa pangan tersedia cukup. Namun demikian, terdapat responden yang menyatakan kurang pangan yang cukup signifikan yaitu 17,5\% dan 20\% di masingmasing desa. Kondisi ini perlu diperhatikan, karena kekurangan pangan ini dapat mengindikasikan rapuhnya ketahanan pangan suatu rumah tangga dan rendahnya tingkat kesejahteraan.

Berdasarkan keterjangkauan atau kemudahan mendapatkan bahan pangan di sekitar tempat tinggal responden, menunjukkan bahwa responden tidak mengalami kesulitan untuk mendapatkan bahan pangan tersebut. Mayoritas reponden menyatakan mudah mendapatkan bahan pangan yang berupa sembako, seperti beras, gula, garam, dan sebagainya di sekitar rumahnya karena tersedia warung atau toko sembako. Jika dibandingkan antara kedua desa penelitian, jumlah responden di Desa Benteng lebih banyak yang menyatakan mudah mendapatakan sembako dibandingkan responden di Desa Cibeber I. Hal ini disebabkan Desa Benteng dekat pusat perekonomian (pasar dan pertokoan), sebaliknya Desa Cibeber I relatif jauh.

Berdasarkan persepsi responden atas harga bahan pangan yang dibelinya, menunjukkan bahwa

Tabel 5. Jumlah dan Persentase Responden berdasarkan Persepsi Kemudahan Mendapatkan Bahan Pangan dalam Rumah Tangga di Desa Benteng dan Desa Cibeber I, 2015

\begin{tabular}{lcccc}
\hline \multirow{2}{*}{$\begin{array}{c}\text { Kemudahan mendapatkan } \\
\text { bahan }\end{array}$} & \multicolumn{2}{c}{ Desa Benteng } & \multicolumn{2}{c}{ Desa Cibeber I } \\
\cline { 2 - 5 } & Jumlah (orang) & Persentase (\%) & Jumlah (orang) & Persentase (\%) \\
\hline Sangat mudah & 3 & 7,5 & 4 & 10,0 \\
Mudah & 37 & 92,5 & 31 & 77,5 \\
Sulit & 0 & 0,0 & 5 & 12,5 \\
Sangat sulit & 0 & 0,0 & 0 & 0,0 \\
\hline Total & 40 & 100,0 & 40 & 100,0 \\
\hline
\end{tabular}


Tabel 6. Jumlah dan Persentase Responden berdasarkan Persepsi tentang Harga Bahan Pangan dalam Rumah Tangga di Desa Benteng dan Desa Cibeber I, 2015

\begin{tabular}{lcccc}
\hline \multirow{2}{*}{ Harga bahan pangan } & \multicolumn{2}{c}{ Desa Benteng } & \multicolumn{2}{c}{ Desa Cibeber I } \\
\cline { 2 - 5 } & $\begin{array}{l}\text { Jumlah } \\
\text { (orang) }\end{array}$ & Persentase (\%) & $\begin{array}{c}\text { Jumlah } \\
\text { (orang) }\end{array}$ & Persentase (\%) \\
\hline Sangat murah & 0 & 0 & 0 & 0,0 \\
Murah & 2 & 5,0 & 6 & 15,0 \\
Mahal & 34 & 80,0 & 27 & 67,5 \\
Sangat mahal & 4 & 10,0 & 7 & 17,5 \\
\hline Total & 40 & 100,0 & 40 & 100,0 \\
\hline
\end{tabular}

mayoritas responden menyatakan harga bahan pangan mahal bahkan beberapa diantaranya menyatakan sangat mahal (Tabel 6). Kondisi ini dapat memperlihatkan bahwa daya beli petani relatif rendah. Di satu sisi harga hasil pertaniannya rendah sebagaimana yang telah dipaparkan sebelumnya dan harga beli pangan tinggi, maka dapat diperkirakan Nilai Tukar Petani (NTN)-nya relatif rendah. NTN merupakan salah satu indikator tingkat kesejahteraan petani yang dihitung dari perbandingan antara harga yang diterima petani (HT) dengan harga yang dibayar petani (HB). Hasil penelitian Sjarief et al. (2014) di Nusa Tenggara Timur juga menunjukkan bahwa harga pangan merupakan salah satu penyebab rendahnya ketahanan pangan di daerah tersebut.

\section{Hubungan antara Penerapan Inovasi teknologi dengan Ketahanan Pangan Rumah Tangga Petani}

Berdasarkan hasil uji Rank Spearman menunjukkan bahwa terdapat korelasi antara intensitas penerapan inovasi teknologi pertanian dengan ketahanan pangan rumah tangga petani di salah satu desa penelitian yaitu Desa Cibeber I (Tabel 7). Hal ini mengindikasikan bahwa rumah tangga petani di Desa Cibeber dengan agroekosistem sawah yang menggunakan inovasi teknologi budidaya padi sawah secara lebih intensif,

Tabel 7. Nilai Koefisien Korelasi antara Intensitas

Penerapan Inovasi Teknologi dengan Ketahanan

Pangan di Desa Benteng dan Desa Cibeber I, 2015

\begin{tabular}{cc}
\hline Desa & Nilai Koefesien Korelasi \\
\hline Desa Benteng & 0,178 \\
Desa Cibeber I & $\mathbf{0 , 3 3 2}^{*}$ \\
\hline
\end{tabular}

kondisi ketahanan pangan rumah tangganya lebih baik dibandingkan dengan petani yang tidak menerapkan secara intensif teknologi tersebut.Sebagai salah satu contohnya sistem jajar legowo. Bagi petani yang intensif menerapkan sistem ini memiliki peluang meningkat pendapatannya dari hasil produktivitasnya yang lebih tinggi, yang dapat membantu penguatan ketahanan pangan rumah tangganya.

Bagi Desa Benteng, inovasi teknologi yang ada tidak berkorelasi dengan ketahanan pangan rumah tangga petani. Artinya teknologi tersebut belum secara signifikan mampu meningkatkan ketahanan pangan rumah tangga petani.

\section{Kesimpulan}

Jenis inovasi teknologi pertanian yang berkembang atau diterapkan oleh petani bergantung pada kondisi agrosistem wilayah setempat. Desa Cibeber I yang berbasis pada lahan basah atau sawah, petani telah banyak yang menerapkan system jajar legowo. Sedangkan untuk desa yang kondisinya berlahan kering dan berbasis pada pengolahan hasil pertanian, petani menerapkan sistem tumpangsari dan teknik-teknik pengolahan hasil pertanian dengan menggunakan mesin.

Terdapat hubungan antara penerapan atau adopsi inovasi teknologi pertanian dengan tingkat ketahanan rumah tangga petani.Terbukti di Desa Cibeber Ipetani yang lebih intensif menerapkan inovasi teknologi seperti jajar legowo memiliki tingkat ketahanan pangan yang lebih baik.

\section{Daftar Pustaka}

Amirian, Baliwati YF, Kustiyah L. 2008.Ketahanan Pangan Rumah tangga Petani Padi sawah di wilayah Enclave Taman Nasional Bukit Barisan Selatan. 
Jurnal Gizi dan Pangan November 2008.3 (3).

Agrotani. 2016. Pengertian Tumpang Sari. [internet].

[dapat diunduh di http://www.agrotani.com/ pengertian-tumpang-sari/].

BBPP Ketindan. 2016. [internet]. [dapat diunduh di http://bbppketindan.bppsdmp.pertanian.go.id/ blog/sistem-jajar-legowo-dapat-meningkatkanproduktifitas-padi].

BPS. 2016. [internet].[dapat diunduh di http://www.bps. go.id/]

Fatchiya A. 2010. Tingkat Kapasitas Pembudidaya Ikan dalam Mengelola Usaha Akuakultur Secara Berkelanjutan. Jurnal Penyuluhan 6 (1): 69-78.

Lippitt, G. 1969. Selective Perspective for Community Resources Developments. Raleigh, North California: Agricultural Policy Institutions.

Nilasari, Fatchiya A, Tjitropranoto, P. 2016. Tingkat Penerapan Pengendalian Hama Terpadu (PHT) Sayuran di Kenagarian Koto Tinggi, Kabupaten
Agam, Sumatera Barat. Jurnal Penyuluhan 12 (1).

Rogers EM. 2003. Diffusion of Innovations. Fifth Edition.The Free Press. A Division of Simon \& Schuster, Inc. 1230 Avenue of The Americas New York. NY 10020.

Suhardianto A, Baliwati YF, Sukandar D. 2007. Ketahanan Pangan Rumah Tanggga Petani Penghasil Beras Organik. Jurnal Gizi dan Pangan 2(3).

Syarief R, Sumardjo, Fatchiya A. 2014. Kajian

Model Pemberdayaan Ketahanan Pangan di Wilayah Perbatasan Antar Negara Jurnal Ilmu Pertanian Indonesia (JIPI). 19(1): 9-13.

Undang-Undang RI Nomor 6 Tahun 2012 tentang Sistem Penyuluhan Pertanian, Perikanan, dan Kehutanan

Undang-Undang RI Nomor 18 Tahun 2012 tentang Pangan 